\title{
Cellular compartmentation of cadmium and zinc in relation to other elements in the hyperaccumulator Arabidopsis halleri
}

\author{
Hendrik Küpper ${ }^{1}$, Enzo Lombi ${ }^{2}$, Fang-Jie Zhao ${ }^{2}$, Steve P. McGrath ${ }^{2}$ \\ ${ }^{1}$ Universität Konstanz, Mathematisch-Naturwissenschaftliche Sektion, Fachbereich Biologie, Fach M665, 78457 Konstanz, Germany \\ ${ }^{2}$ IACR-Rothamsted, Soil Science Department, Harpenden, Herts., AL5 2JQ, UK
}

Received: 4 April 2000 / Accepted: 16 May 2000

\begin{abstract}
The cellular compartmentation of elements was analysed in the $\mathrm{Zn}$ hyperaccumulator Arabidopsis halleri (L.) O'Kane \& Al-Shehbaz (=Cardaminopsis halleri) using energy-dispersive X-ray microanalysis of frozen-hydrated tissues. Quantitative data were obtained using oxygen as an internal standard in the analyses of vacuoles, whereas a peak/background ratio method was used for quantification of elements in pollen and dehydrated trichomes. Arabidopsis halleri was found to hyperaccumulate not only $\mathrm{Zn}$ but also $\mathrm{Cd}$ in the shoot biomass. While large concentrations of $\mathrm{Zn}$ and $\mathrm{Cd}$ were found in the leaves and roots, flowers contained very little. In roots grown hydroponically, $\mathrm{Zn}$ and $\mathrm{Cd}$ accumulated in the cell wall of the rhizodermis (root epidermis), mainly due to precipitation of $\mathrm{Zn} / \mathrm{Cd}$ phosphates. In leaves, the trichomes had by far the largest concentrations of $\mathrm{Zn}$ and $\mathrm{Cd}$. Inside the trichomes there was a striking sub-cellular compartmentation, with almost all the $\mathrm{Zn}$ and $\mathrm{Cd}$ being accumulated in a narrow ring in the trichome base. This distribution pattern was very different from that for $\mathrm{Ca}$ and $\mathrm{P}$. The epidermal cells other than trichomes were very small and contained lower concentrations of $\mathrm{Zn}$ and $\mathrm{Cd}$ than mesophyll cells. In particular, the concentrations of $\mathrm{Cd}$ and $\mathrm{Zn}$ in the mesophyll cells increased markedly in response to increasing $\mathrm{Zn}$ and $\mathrm{Cd}$ concentrations in the nutrient solution. This indicates that the mesophyll cells in the leaves of $A$. halleri are the major storage site for $\mathrm{Zn}$ and $\mathrm{Cd}$, and play an important role in their hyperaccumulation.
\end{abstract}

Key words: Arabidopsis (Cd, $\mathrm{Zn}$ accumulation) Cadmium accumulation -

Cellular compartmentation - Hyperaccumulation (heavy metals) - Trichome - Zinc accumulation

\footnotetext{
Abbreviations: $\quad$ EDXA $=$ energy dispersive X-ray analysis; $\mathrm{SEM}=$ scanning electron microscope

Correspondence to: $\mathrm{S}$. P. McGrath;

E-mail: steve.mcgrath@bbsrc.ac.uk; Fax: +44-1582-760981
}

\section{Introduction}

Many heavy metals, e.g. $\mathrm{Cu}, \mathrm{Zn}, \mathrm{Ni}$, $\mathrm{Co}$ and $\mathrm{Mn}$, are essential trace elements for plants, but can be highly toxic when present at large concentrations. For most plant species, the range of beneficial concentrations of these metals is often very narrow (Marschner 1995). Other heavy metals such as $\mathrm{Cd}$ are not essential and are also highly toxic.

Plants have developed different tolerance strategies to grow on soils rich in heavy metals. A large number of tolerant plants are so-called "excluders": they are able to restrict root uptake, and in particular, root-toshoot translocation of heavy metals (Baker 1981). Some plant species, however, have developed a strategy that is the opposite to that of the "excluders": they accumulate heavy metals to exceedingly high levels in the aboveground parts. The term "hyperaccumulator" was introduced by Brooks et al. (1977) for plants that accumulate more than $1 \mathrm{mg} \mathrm{Ni}$ per gram of dry weight in their shoots in their natural habitats. To date, more than 400 species of hyperaccumulators belonging to 45 families have been identified, of which about $75 \%$ are Ni-hyperaccumulators (Brooks 1998; Baker et al. 2000). So far, about 18 species of $\mathrm{Zn}$ hyperaccumulator have been identified. A Zn-hyperaccumulator is defined as a plant that accumulates at least $10 \mathrm{mg} \mathrm{Zn}$ per gram of dry weight in shoots in its natural habitat (Brooks 1998). Thlaspi caerulescens J.\&C. Presl (Brassicaceae) is the best-known Znhyperaccumulator (Baker et al. 2000). This species can also hyperaccumulate $\mathrm{Cd}\left(>0.1 \mathrm{mg} \mathrm{g}^{-1}\right.$ dry weight of shoots), although recent results showed that different ecotypes of $T$. caerulescens varied greatly in their capacity to take up Cd (Lombi et al. 2000). Driven by the potential of their use to extract and remove toxic metals from contaminated soils (McGrath 1998; Salt et al. 1998), there has been recent progress in our understanding of the uptake, translocation and compartmentation of heavy metals, particularly in Ni-hyperaccumulators in the genus Alyssum and in T. goesingense (Krämer et al. 1997; Salt et al. 
2000), and in the Zn-hyperaccumulator T. caerulescens (Lasat et al. 1996, 2000; Shen et al. 1997; Küpper et al. 1999; Salt et al. 1999).

Although Arabidopsis halleri (L.) O'Kane \& AlShehbaz (previously known as Cardaminopsis halleri) has long been known as a Zn-hyperaccumulator (Brooks 1998), there have been very few studies on the uptake, tolerance and cellular compartmentation of the metal in this species. By crossing A. halleri with a non-hyperaccumulating, non-tolerant species Arabidopsis petraea, Macnair et al. (1999) found that $\mathrm{Zn}$ tolerance and hyperaccumulation are genetically independent characters. A recent study showed that $A$. halleri can accumulate up to $32 \mathrm{mg} \mathrm{g}^{-1} \mathrm{Zn}$ in shoots without suffering from phytotoxicity in hydroponic culture, and that $\mathrm{Zn}$ is accumulated preferentially in the trichomes (Zhao et al. 2000). These preliminary results suggested that the cellular compartmentation of $\mathrm{Zn}$ in $A$. halleri is very different from that found in $T$. caerulescens leaves (Küpper et al. 1999).

The aim of the present study was to quantify the cellular distribution of both $\mathrm{Zn}$ and $\mathrm{Cd}$ in different tissues of $A$. halleri. A new method was developed to allow in-situ quantitative measurements of $\mathrm{Cd}$ and $\mathrm{Zn}$ in vacuoles. Furthermore, we investigated the responses in terms of cellular distribution of $\mathrm{Zn}, \mathrm{Cd}$ and other major elements to different $\mathrm{Zn} / \mathrm{Cd}$ treatments in nutrient solution.

\section{Materials and methods}

\section{Plant culture}

Seeds of Arabidopsis halleri (L.) O'Kane \& Al-Shehbaz were germinated on a mixture of perlite and vermiculite moistened with deionised water. Three weeks after germination, seedlings were transferred to $1-\mathrm{L}$ vessels containing (in $\mu \mathrm{M}$ ) $1000 \mathrm{Ca}\left(\mathrm{NO}_{3}\right)_{2}, 500$ $\mathrm{MgSO}_{4}, 50 \mathrm{~K}_{2} \mathrm{HPO}_{4}, 100 \mathrm{KCl}, 10 \mathrm{H}_{3} \mathrm{BO}_{3}, 1.8 \mathrm{MnSO}_{4}, 0.2$ $\mathrm{Na}_{2} \mathrm{MoO}_{4}, 0.31 \mathrm{CuSO}_{4}, 0.5 \mathrm{NiSO}_{4}, 50 \mathrm{Fe}$ (III)-HBED (Fe(III)$\mathrm{N}, \mathrm{N}^{\prime}$-bis(2-hydroxybenzyl)-ethylenediamine-N,N'-diacetate), and 5 $\mathrm{ZnSO}_{4}$ (Shen et al. 1997). Solution $\mathrm{pH}$ was maintained at around 6.0 with $2000 \mu \mathrm{M}$ Mes (2-morpholinoethanesulphonic acid, $50 \%$ as potassium salt). Three weeks later the chelating agent for $\mathrm{Fe}$ was changed to EDDHA [ethylenediamine-di(o-hydroxyphenylacetic acid)]. There were four $\mathrm{Zn} / \mathrm{Cd}$ treatments: Control $(5 \mu \mathrm{M} \mathrm{Zn}$, no addition of $\mathrm{Cd}$ ); $500 \mu \mathrm{M} \mathrm{Zn}$, no addition of $\mathrm{Cd} ; 5 \mu \mathrm{M} \mathrm{Zn}, 100 \mu \mathrm{M}$ $\mathrm{Cd}$; and $500 \mu \mathrm{M} \mathrm{Zn}, 100 \mu \mathrm{M} \mathrm{Cd}$. Both $\mathrm{Zn}$ and $\mathrm{Cd}$ were added as sulfates, i.e. as divalent cations. As both ions are biologically redoxinert, this will also be their oxidation state inside the plants. However, since energy-dispersive X-ray microanalysis (EDXA) does not provide information about oxidation states of the elements measured, throughout the following they will be mentioned as $\mathrm{Zn} / \mathrm{Cd}$ instead of $\mathrm{Zn}^{2+} / \mathrm{Cd}^{2+}$.

Each treatment was replicated in three vessels, each containing four plants. The treatments were started 2 weeks after seedlings were transferred to hydroponics. The nutrient solution was aerated continuously and renewed every $3 \mathrm{~d}$ until the plants were flowering (14 weeks). Plants were grown in a controlled environment room with the following conditions: $16 \mathrm{~h}$ day length with a photon flux density of $350 \mu \mathrm{mol} \mathrm{m} \mathrm{m}^{-1} \mathrm{~s}^{-1}$ supplied by fluorescent tubes, $20^{\circ} \mathrm{C} /$ $16{ }^{\circ} \mathrm{C}$ day/night temperature, and $60-70 \%$ humidity.

\section{Freeze-fracturing and EDXA}

Sections of plant tissue were excised and mounted in a stainlesssteel vice, or, when leaf surfaces with trichomes were analysed, mounted flat on the surface of carbon stubs using conductive carbon tabs. Samples were then rapidly (within less than a minute after excision) frozen in melting nitrogen slush and transferred to a fracturing chamber cooled to $-170{ }^{\circ} \mathrm{C}$. For root and leaf crosssections, a blade was used to cut through the cells rather than breaking the tissue at the cell surfaces. Subsequently, samples were evaporatively coated with carbon to produce an electrically conductive surface and thus prevent charging under the electron beam. Carbon was used instead of metal coating to avoid interference on the elements measured. Energy dispersive X-ray analysis was performed in a scanning electron microscope (SEM; Philips XL 40) on a cryostage $\left(-160{ }^{\circ} \mathrm{C}\right.$ to $\left.-180{ }^{\circ} \mathrm{C}\right)$, using an acceleration voltage of $30 \mathrm{kV}$ and a working distance of $10 \mathrm{~mm}$. With this accelerating voltage, the maximum penetration depth of the electron beam is about 10 to $15 \mu \mathrm{m}$ (leading to a vertical resolution of 5-8 $\mu \mathrm{m}$ ). In contrast, the horizontal resolution (determined mainly by the diameter of the electron beam) is better than $1 \mu \mathrm{m}$. Hence, differences in concentration, e.g. between small organelles such as chloroplasts or mitochondria and the cytoplasm cannot be resolved. However, differences between the cell wall and the vacuole can be assessed if the cell wall being measured is approximately parallel to the electron beam.

The distribution of $\mathrm{Zn}$ across a section of a sample was measured semi-quantitatively by displaying the count rate within a narrow spectrum window within its peak $(0.6 \times$ peak half-width $)$ along a transect line. A two-dimensional distribution pattern was also recorded by scanning an area of the specimen repeatedly for up to $2 \mathrm{~h}$ and integrating the counts for $\mathrm{Zn}, \mathrm{Cd}, \mathrm{Ca}$ and $\mathrm{K}$ within their respective spectrum windows into dot-maps. In both line and area scans, the spectrum-analysis software did not allow for the separation of the element-specific X-rays (net peak counts) from the background counts. Therefore, these scans were performed only on those elements with a peak/background ratio greater than two. A dot-map of oxygen distribution was recorded before analysis of the specimen. Because of its low energy, the X-rays emitted by oxygen are most strongly affected by shading (caused by the vice or neighboring cells) inside the sample, so that an oxygen dot-map clearly shows these shaded parts of the sample. The regions of specimen that suffered from shading effects were not used for quantitative analysis. Additionally, the collection of oxygen dotmaps enabled the distinction between hydrated (living) and dry (dead) trichomes.

Spectra from 0 to $20 \mathrm{keV}$ were collected at increments of $10 \mathrm{eV}$ per channel with the electron beam focused on a rectangular area in the centre of selected cells. The spectra were analysed using the program Superquant (EDAX, San Francisco, Calif., USA), which separates the background from the element-specific peaks and fully deconvolutes the spectra for the correction of interference between elements. Thus, the analysis with this program yielded the net peak count rate and the peak/background ratio for each element, which were used for quantification as described below.

For quantification of EDXA data in a biological sample of unknown composition, usually a known amount of substance which is not present in the sample (e.g. a rare element like $R b$ ) is added as an internal standard (e.g. Tomos et al. 1994). The use of an internal standard is necessary because the net count rate (counts/s) inside the X-ray emission peak depends not only on the concentration of the element, but also on the working distance, the beam current, and the shape of the specimen. Additionally, at higher concentrations the count rates are saturating (Fig. 1A and B). Although adding an internal standard to overcome these problems represents a possible solution for samples extracted from a tissue by the use of micropipettes (Tomos et al. 1994; Küpper et al. 1999), it is not suitable for in situ analysis of biological samples. Additionally, only very few types of tissue are accessible to sampling with micropipettes.

In this study, we used the signal of endogenous oxygen as an internal standard to quantify the concentrations of several elements in frozen hydrated samples. This approach is based on the fact that the vacuole of a living cell contains about $80-90 \%$ water. Hence, we assumed that every vacuole contained $85 \%$ water, allowing up 

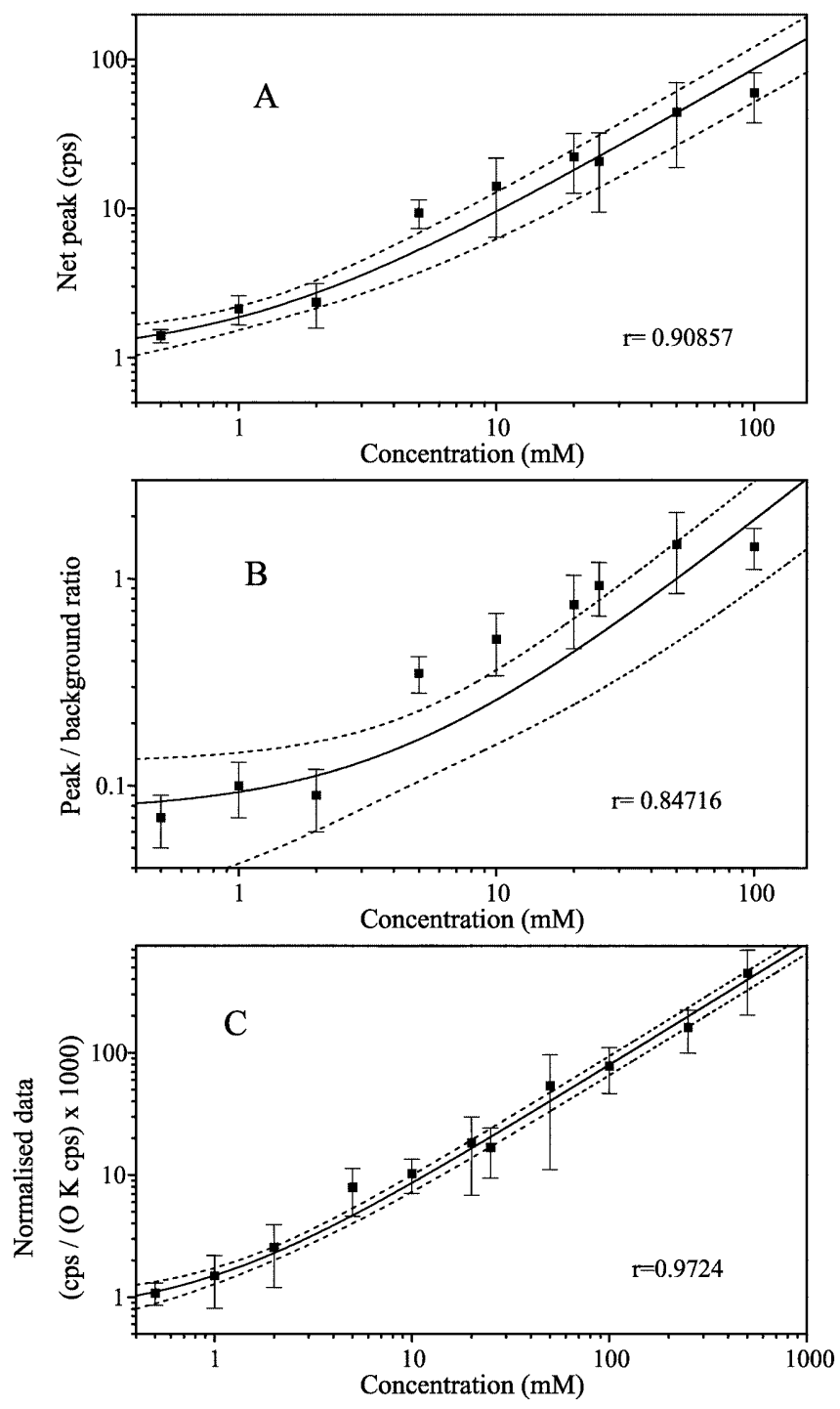

Fig. 1A-C. Comparison of methods for using EDXA data as a quantitative measure of in-situ element concentrations in frozen multielement standards. For all elements except $\mathrm{Cd}$, the $\mathrm{K} \alpha \mathrm{X}$-ray emission lines were used for quantification. In this figure for $\mathrm{Cd}$, the $\mathrm{L} \alpha$ line was used instead because of the high energy of the $\mathrm{K} \alpha$ line of this element. The graphs were obtained by linear regressions with error bars as weights. A Net peak counts. B Peak/background ratio. C Net peak counts/oxygen net peak counts

to $\pm 10 \%$ error. This method extended the linear portion of the calibration curve to much higher concentrations (Fig. 1C), because the effects of instrumental conditions on element-specific peak counts were cancelled out by similar effects on oxygen. The quantification was calibrated (to obtain the element-specific emission efficiency) using multi-element standards. Hence the final formula for quantification of an element was obtained as: (net peak counts $) \times($ emission efficiency $) \times(\text { net oxygen counts })^{-1}$. Using this method, a reliable quantification $( \pm 15 \%)$ within the concentration range 5-500 $\mathrm{mM}$ was achieved for $\mathrm{Zn}, \mathrm{Ca}, \mathrm{Cd}, \mathrm{Cl}, \mathrm{K}, \mathrm{Mg}$ and $\mathrm{P}$. The data for $\mathrm{Cd}$ are shown as an example in Fig. 1C.

For samples that have a highly variable or low water content (e.g. pollen, dehydrated trichomes), the reliability of the method is less certain. In these cases, a calibration between peak/background ratios for specific elements and their concentrations in the standard solutions was used to quantify the data recorded (Boekestein et al. 1984; Van Steveninck and Van Steveninck 1991). In such samples, the term "concentration" refers to the apparent concentration of the element, meaning that not all of this is in soluble form.

\section{Determination of element concentrations in whole plant tissues}

Plants were harvested after growing on different treatments for 14 weeks. The plants were divided into roots and shoots, washed with deionised water and blotted dry. The samples were then oven-dried for $72 \mathrm{~h}$ and dry weights determined. Dried samples were ground and a 0.2 -g sub-sample was digested with a mixture of $\mathrm{HNO}_{3}$ and $\mathrm{HClO}_{4}$. Concentrations of $\mathrm{Cd}, \mathrm{Zn}$ and other elements in the digests were determined using inductively coupled atomic emission spectrometry (ICP-AES; Fisons ARL Accuris).

\section{Results}

\section{Plant growth and elemental composition}

Visual observations of the plant growth showed healthy growth of plants in all treatments except $5 \mu \mathrm{M} \mathrm{Zn+}$ $100 \mu \mathrm{M} \mathrm{Cd}$. Plants in this treatment were chlorotic. The observations of growth were confirmed by the biomass data at the end of the experiment: while the treatments with $500 \mu \mathrm{M} \mathrm{Zn}$ and $500 \mu \mathrm{M} \mathrm{Zn}+100 \mu \mathrm{M}$ Cd showed no significant ( $t$-test, $P>0.05, n=9$ ) differences compared to the control $(5 \mu \mathrm{M} \mathrm{Zn})$, the plants treated with $5 \mu \mathrm{M} \mathrm{Zn}+100 \mu \mathrm{M} \mathrm{Cd}$ had approximately $40 \%$ reduced shoot and $60 \%$ reduced root biomass (Table 1).

With $5 \mu \mathrm{M} \mathrm{Zn}$ in the nutrient solution, $\mathrm{Zn}$ was primarily accumulated in the shoots. At the higher $\mathrm{Zn}$ concentration $(500 \mu \mathrm{M} \mathrm{Zn})$, the concentration of $\mathrm{Zn}$ in the roots exceeded that in the shoots. This was probably due to precipitation in the root apoplast. In comparison, the $\mathrm{Cd}$ concentration in roots was always larger than in shoots. When either $\mathrm{Cd}$ or $\mathrm{Zn}$ was present in the nutrient solution at large concentrations $(100 \mu \mathrm{M} \mathrm{Cd}+5 \mu \mathrm{M}$ $\mathrm{Zn}, 500 \mu \mathrm{M} \mathrm{Zn}$ ), the plants accumulated almost $6,000 \mathrm{mg}$ $\mathrm{Cd} \mathrm{kg}^{-1}$ or $9500 \mathrm{mg} \mathrm{Zn} \mathrm{kg}^{-1}$ in the shoots (Table 1). In the treatments with $100 \mu \mathrm{M} \mathrm{Cd}$, increasing $\mathrm{Zn}$ from 5 to $500 \mu \mathrm{M}$ decreased the $\mathrm{Cd}$ concentration in the shoots by half. This probably explains why phytotoxicity only occurred in the $5 \mu \mathrm{M} \mathrm{Zn}+100 \mu \mathrm{M}$ Cd treatment.

Concentrations of other elements were influenced by the different treatments (Table 1). All treatments with elevated $\mathrm{Zn}$ or $\mathrm{Cd}$ concentrations led to a decrease of $\mathrm{Mn}$ and $\mathrm{Fe}$ in the shoots. In contrast, the shoot concentration of $\mathrm{S}$ increased in both $\mathrm{Cd}$ treatments, especially in the plants grown in $5 \mu \mathrm{M} \mathrm{Zn}+100 \mu \mathrm{M}$ $\mathrm{Cd}$. In this treatment, the shoot concentration of $\mathrm{Mg}$ was also significantly ( $t$-test, $P<0.001, n=6)$ increased compared to the control. In the roots, all treatments with elevated $\mathrm{Cd}$ or $\mathrm{Zn}$ showed an increase in $\mathrm{P}$ concentrations, with a maximum in the $500 \mu \mathrm{M}$ $\mathrm{Zn}+100 \mu \mathrm{M}$ Cd treatment.

\section{X-ray microanalysis of frozen-hydrated tissues}

Roots. In the control treatment the average concentrations of $\mathrm{Zn}$ and $\mathrm{Cd}$ in roots were below the detection limit of EDXA (i.e. $<5 \mathrm{mM}$ ). However, in the $100 \mu \mathrm{M}$ 


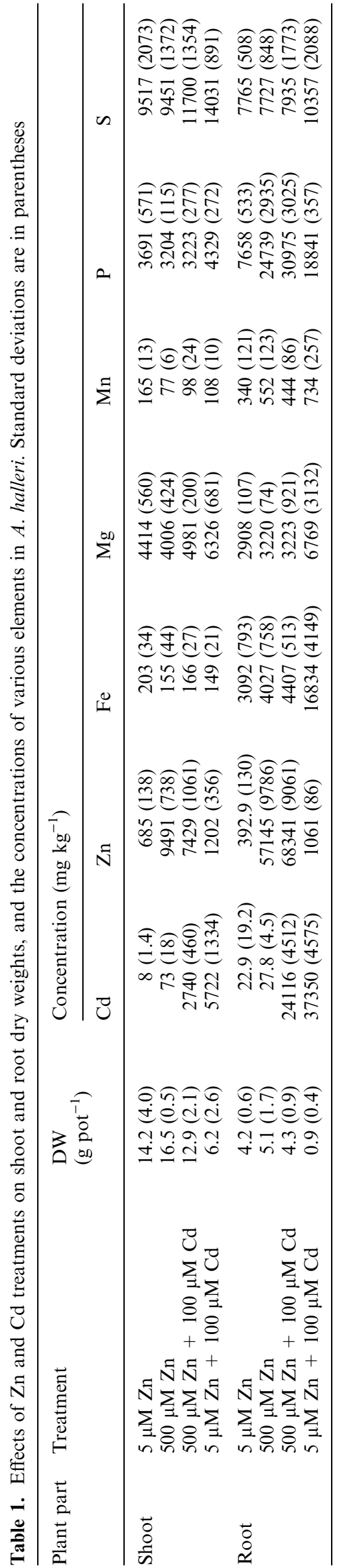

Cd treatment a gradient was found with the highest $\mathrm{Cd}$ concentrations in the rhizodermal (root epidermal) cell walls and the lowest in the central cylinder (Table 2). In the $500 \mu \mathrm{M} \mathrm{Zn}$ treatments (with or without $100 \mu \mathrm{M}$ $\mathrm{Cd}$ ), the outer cell wall of the root rhizodermis accumulated so much $\mathrm{Zn}$ that the peak/background ratio was high enough for recording dot-maps and linescans of Zn distribution (Fig. 2). The dot-maps clearly showed bright spots of $\mathrm{Zn}$ accumulation, which correlated with high concentrations of P. Additionally, the line-scans (Fig. 2) and quantitative analyses (Table 2) showed that there was a second, smaller peak of $\mathrm{P}$ concentration in the central cylinder, which did not relate to the $\mathrm{Zn}$ concentration. Concentrations of $\mathrm{Zn}$ and $\mathrm{Cd}$ in all parts of the roots, except the outer epidermal cell walls, were at or below the detection limit of EDXA (i.e. $<5 \mathrm{mM}$ ).

Leaves. As displayed quantitatively in Fig. 3, the highest $\mathrm{Zn}$ and $\mathrm{Cd}$ concentrations were found in the bases of trichomes on the leaf surface. A closer view shows that this accumulation was restricted to a very narrow area in the upper part of the trichome base (Fig. 4). Concentrations of $\mathrm{Zn}$ and $\mathrm{Cd}$ in this compartment can be higher than $1 \mathrm{M}$ (Fig. 3). Line-scans of a hydrated trichome show that there was more oxygen in the base than in the upper part of the trichome (Fig. 4). In contrast, Ca was highly enriched in the upper part of the trichome, with little accumulation in the basal compartment where $\mathrm{Zn}$ accumulated. The signal of $\mathrm{P}$ also decreased from the top to the base of trichome, indicating that $\mathrm{Zn}$ accumulation in the trichome base was not associated with P. Also, S was not present in elevated amounts in the compartment where $\mathrm{Zn}$ and $\mathrm{Cd}$ accumulated (Fig. 3). Based on the oxygen signal, around half of the trichomes on the leaves of $A$. halleri examined were dehydrated. However, the localisation of $\mathrm{Zn}$ and $\mathrm{Cd}$ in dead and living trichomes was identical (Fig. 5).

The $\mathrm{Zn}$ and $\mathrm{Cd}$ accumulation inside the leaf was not homogeneous. The average concentrations in the epidermis were usually two to three times lower than those in the mesophyll cells (Fig. 6). Inside the mesophyll there were few cells which accumulated very high concentrations: up to $70 \mathrm{mM} \mathrm{Zn}$ and $10 \mathrm{mM} \mathrm{Cd}$ in the $500 \mu \mathrm{M} \mathrm{Zn}+100 \mu \mathrm{M}$ Cd treatment. In this treatment, mesophyll cells also showed a strong positive linear correlation between the concentrations of $\mathrm{Zn}$ and $\mathrm{Cd}$ in single cells $(r=0.94, P<0.001, n=12)$.

The increased $\mathrm{Mg}$ concentration in the shoots from the $5 \mu \mathrm{M} \mathrm{Zn}+100 \mu \mathrm{M} \mathrm{Cd}$ treatment, which was phytotoxic, was confirmed by EDXA at the single-cell level: in mesophyll and epidermal cells of this treatment there was a strong $(r=0.79, P<0.0001, n=26)$ positive correlation between $\mathrm{Mg}$ and $\mathrm{Cd}$, with a $\mathrm{Mg} / \mathrm{Cd}$ ratio of $2.1( \pm 0.3 \mathrm{SE})$. No such correlation was found between these metals in any of the other treatments and other types of cell at the single-cell level. Also, no correlation between $\mathrm{Zn}$ and $\mathrm{Mg}$ was found.

Increasing external $\mathrm{Zn}$ concentrations led to a much greater increase in $\mathrm{Zn}$ accumulation in the mesophyll 
Table 2. Concentrations of various elements in root tissues of $A$. halleri quantified using EDXA. Standard deviations are in parentheses. For brevity, only two treatments are reported

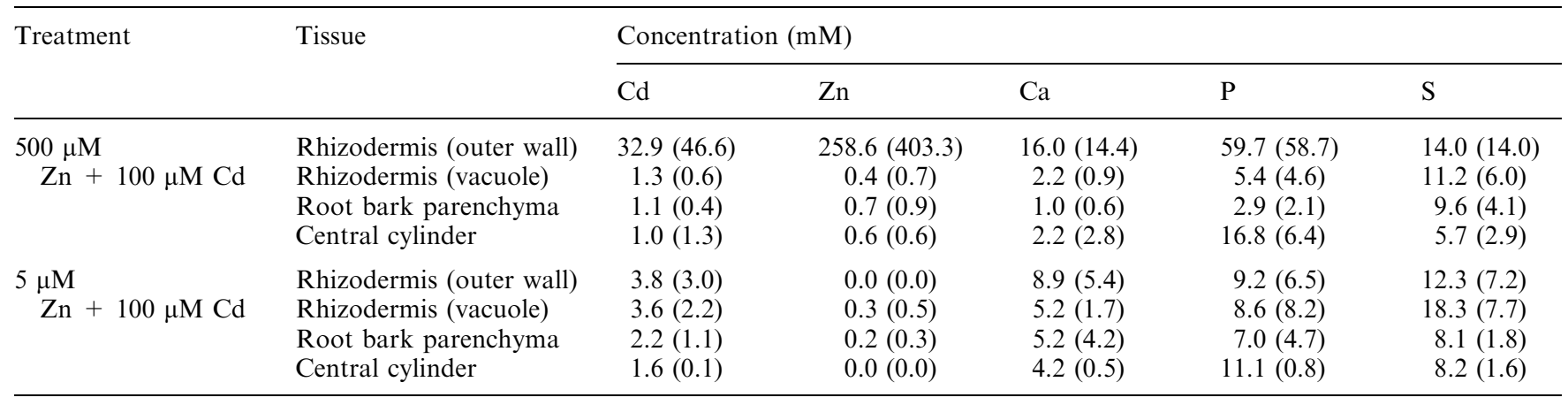
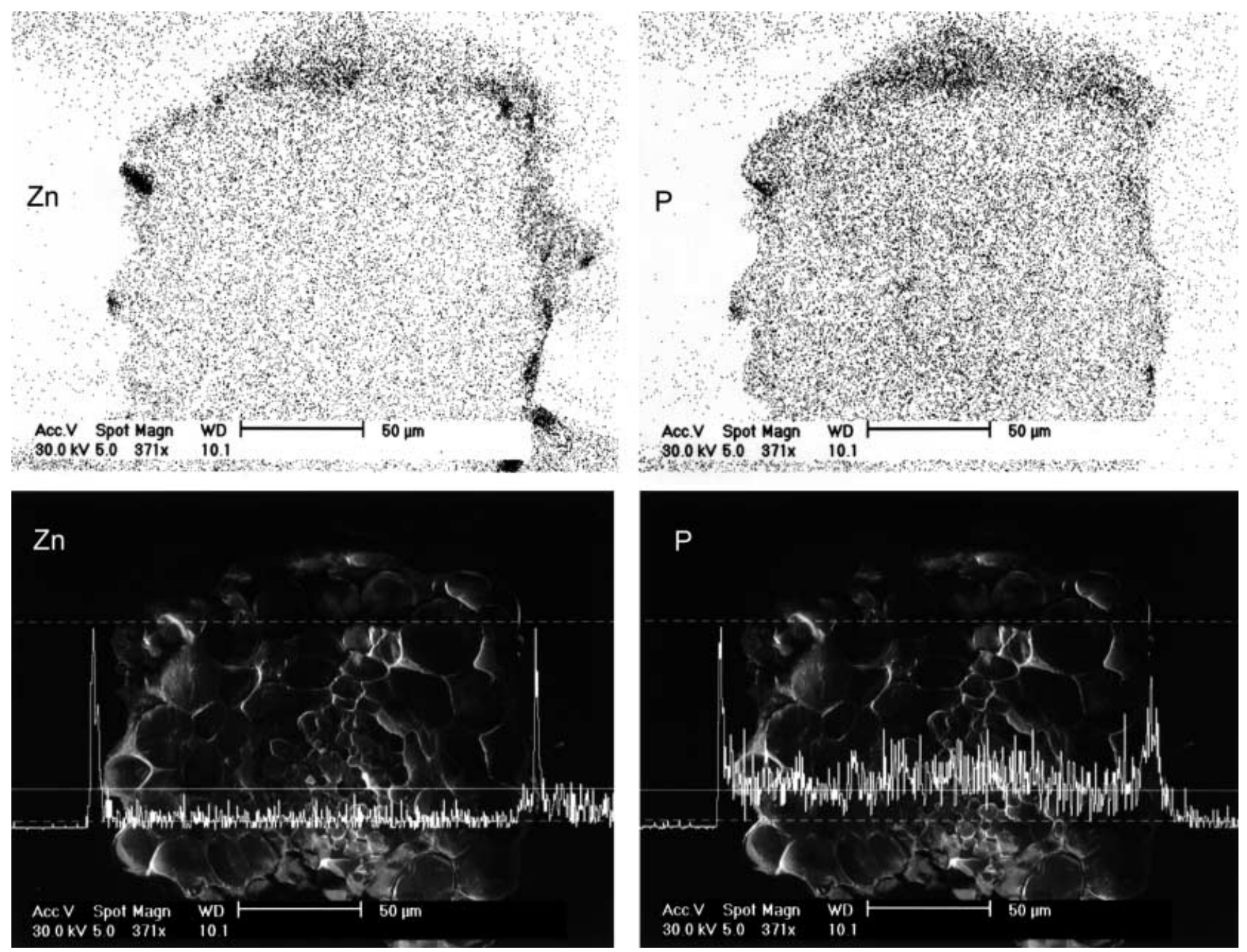

Fig. 2. Precipitations of zinc and phosphorus in the outer cell wall of the epidermis of $A$. halleri roots as shown by a scan of a root crosssection. The analyses were performed in an SEM using an acceleration voltage of $30 \mathrm{kV}$ and a working distance of $10 \mathrm{~mm}$. Dot maps and

line scans were obtained by selecting an energy window $(0.6 \times$ halfwidth) inside an X-ray emission line of the element to be measured. Upper, dot maps of EDXA counts; lower, line scans of EDXA counts; left, zinc; right, phosphorus

cells than in the trichomes (Figs. 3 and 6). For example, the spongy mesophyll cells in the $500 \mu \mathrm{M}$ $\mathrm{Zn}+100 \mu \mathrm{M} \mathrm{Cd}$ treatment accumulated on average more than $30 \mathrm{mM} \mathrm{Zn}$, representing an increase of more than 30-fold compared to the control. In contrast,

concentrations in the trichomes increased by only 3 -fold.

In the leaves, the concentration of $\mathrm{K}$ was larger in the epidermis than in mesophyll cells, whereas the opposite was observed for Ca (Fig. 6). 

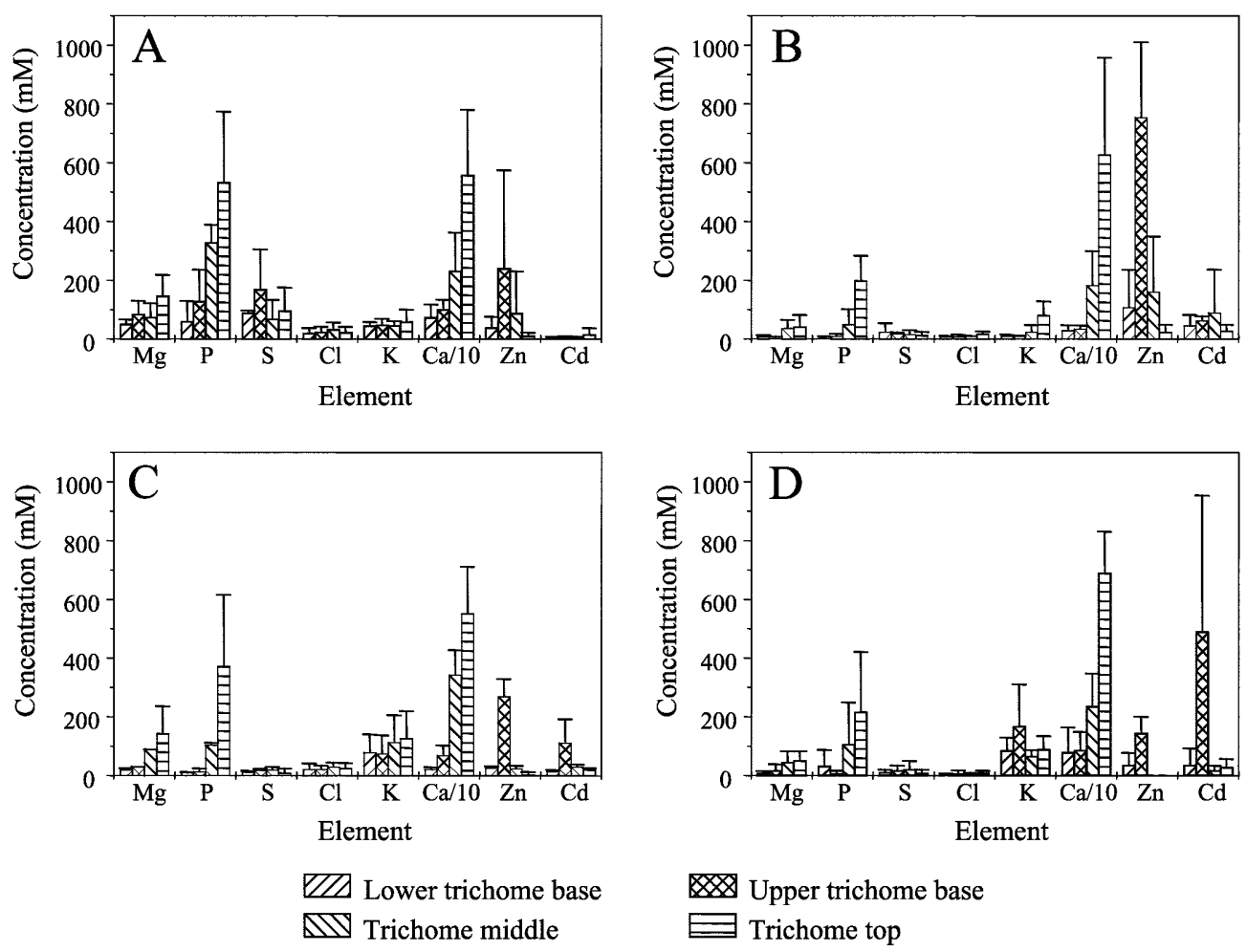

Fig. 3A-D. X-ray microanalysis data from different parts of A. halleri leaf trichomes. The (apparent) $\mathrm{Ca}$ concentrations are divided by 10 to make them fit into the graph and thus enable the comparison of the $\mathrm{Ca}$ distribution pattern with that of the other elements. A control $(5 \mu \mathrm{M}$ $\mathrm{Zn})$. B Grown with $500 \mu \mathrm{M} \mathrm{Zn}$. C Grown with $500 \mu \mathrm{M}$ $\mathrm{Zn}+100 \mu \mathrm{M}$ Cd. D Grown with $5 \mu \mathrm{M} \mathrm{Zn}+100 \mu \mathrm{M} \mathrm{Cd}$

Flowers. Flowers contained only very small amounts of $\mathrm{Zn}$ and $\mathrm{Cd}$, usually at the detection limit of EDXA (i.e. $<5 \mathrm{mM}$, data not shown). While the concentrations of various elements were not significantly $(t$-test, $P>0.05$, $n=53$ ) changed by the different $\mathrm{Zn} / \mathrm{Cd}$ treatments, the toxic $5 \mu \mathrm{M} \mathrm{Zn}+100 \mu \mathrm{M}$ Cd treatment resulted in a reduced size of the flowers as well as a 4- to 5-week earlier blossoming compared to the $500 \mu \mathrm{M} \mathrm{Zn}$ treatment.

\section{Discussion}

Zhao et al. (2000) showed that $A$. halleri has accumulation and tolerance capabilities for $\mathrm{Zn}$ comparable to the well-known $\mathrm{Zn} / \mathrm{Cd}$-hyperaccumulator $T$. caerulescens. The smaller concentration of $\mathrm{Zn}$ in shoots, recorded in the present study, in comparison to the results obtained by Zhao et al. (2000) was probably due to the much larger biomass per pot obtained in this experiment (almost 3 times higher). The present study shows that $A$. halleri is also able to accumulate $\mathrm{Cd}$ up to almost $6,000 \mathrm{mg} \mathrm{kg}^{-1}$ on a dry-weight basis in shoots, although at this level phytotoxicity was observed. No phytotoxicity occurred at a $\mathrm{Cd}$ concentration of $2,700 \mathrm{mg} \mathrm{kg}^{-1}$ in shoots, suggesting that $A$. halleri can be considered to be a hyperaccumulator of this metal. However, there is no report of $\mathrm{Cd}$ hyperaccumulation by $A$. halleri in its natural habitat.

The changes in nutrient balance observed in the $5 \mu \mathrm{M}$ $\mathrm{Zn}+100 \mu \mathrm{M} \mathrm{Cd}$ may be related to the toxic effect of $\mathrm{Cd}$. In fact, the concentrations of $\mathrm{Mg}$ and $\mathrm{S}$ were significantly enhanced in shoots by this treatment.
Furthermore, on the single-cell level a strong positive correlation between $\mathrm{Mg}$ and $\mathrm{Cd}$ concentrations was found. These observations may be explained by a defence reaction of the plants. The increased $\mathrm{Mg}$ concentration may reduce $\mathrm{Cd}$ substitution on chlorophyll, which has been shown to be an important damage mechanism in heavy-metal-stressed plants (Küpper et al. 1996). The role of $\mathrm{S}$ compounds (i.e. glutathione, phytochelatin) in the detoxification of $\mathrm{Cd}$ is well documented (e.g. Steffens 1990; Salt et al. 1995; Kneer and Zenk 1992; Zhu et al. 1999). In contrast, Zn hyperaccumulation in the shoots of $A$. halleri was not associated with $\mathrm{S}$ accumulation. The comparison of the two treatments with $100 \mu \mathrm{M} \mathrm{Cd}$ in the nutrient solution revealed that in $A$. halleri increased levels of $\mathrm{Zn}$ reduce $\mathrm{Cd}$ toxicity by reducing $\mathrm{Cd}$ uptake.

\section{Cellular compartmentation of $\mathrm{Zn}, \mathrm{Cd}$ and other elements in different tissues}

The EDXA results provide clear evidence of the precipitation of $\mathrm{Zn} / \mathrm{Cd}$ phosphates in the apoplast outside the root rhizodermis. This is not surprising because the speciation programme GEOCHEM PC (Parker et al. 1995) predicted formation of $\mathrm{Zn} / \mathrm{Cd}$ and phosphate precipitates when $\mathrm{Zn}$ and $\mathrm{Cd}$ in the nutrient solution were at 500 and $100 \mu \mathrm{M}$, respectively. Our previous results for plants grown hydroponically also showed a ratio of insoluble $\mathrm{Zn}$ to insoluble $\mathrm{P}$ in the roots of $A$. halleri that was very close to the stoichiometric ratio of $\mathrm{Zn}_{3}\left(\mathrm{PO}_{4}\right)_{2}$ (Zhao et al. 2000). Further work is needed to elucidate whether apoplastic precipitation of 

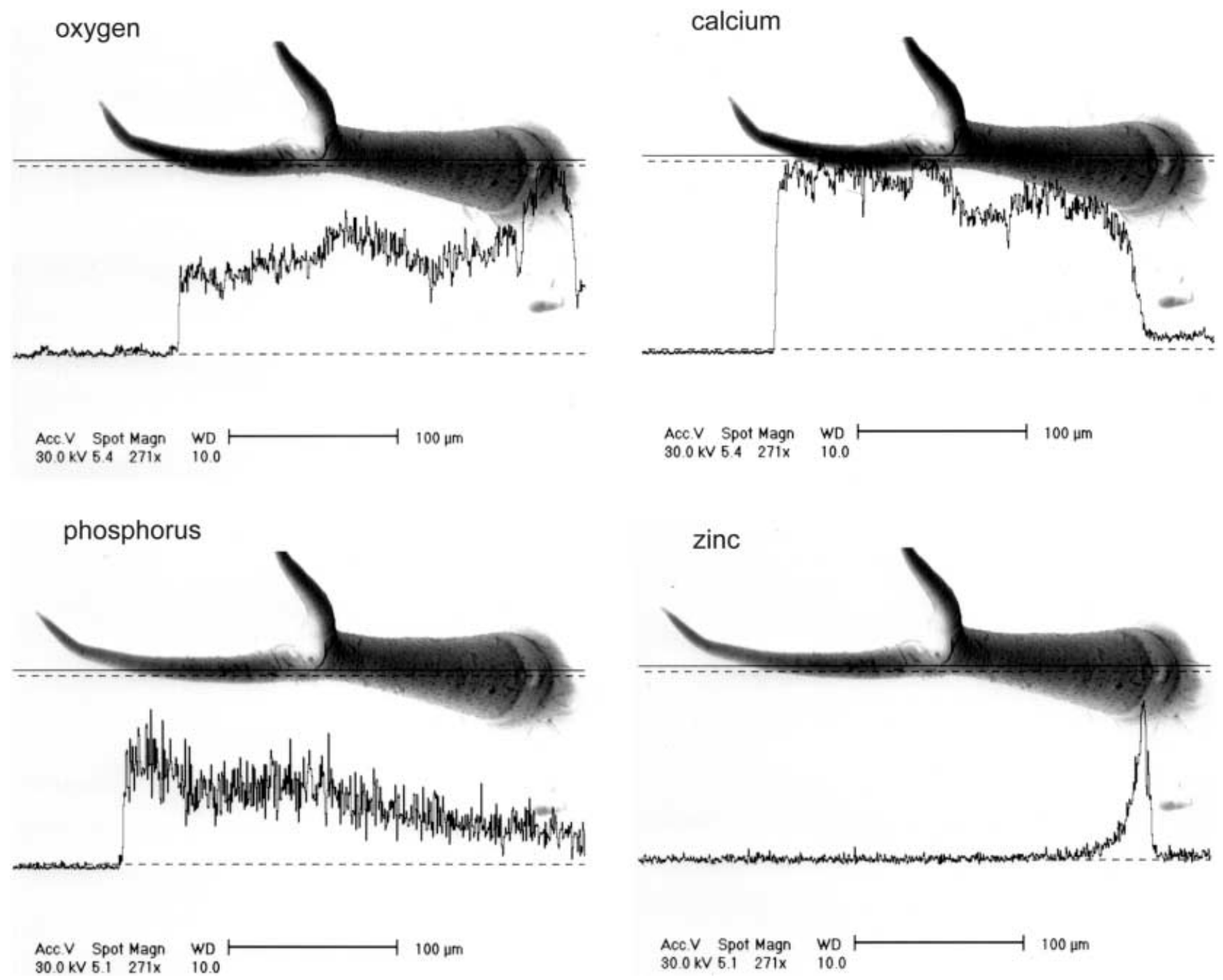

Fig. 4. Distribution of elements in a trichome of A. halleri treated with $500 \mu \mathrm{M} Z \mathrm{Zn}$. Line scans of EDXA counts of oxygen, calcium, phosphorus and zinc. See Fig. 2 for explanation of SEM parameters

$\mathrm{Zn} / \mathrm{Cd}$ with phosphate occurs under natural environmental conditions. We think this is unlikely, because the movement of $\mathrm{P}$ in the rhizosphere is always limited by diffusion, resulting in depletion rather than accumulation of $\mathrm{P}$ at the root surface (Marschner 1995). Depletion of $\mathrm{Zn}$ and $\mathrm{Cd}$ may also occur in the rhizosphere of hyperaccumulator plants because of their rapid uptake systems (Lasat et al. 2000). Knight et al. (1997) showed that mass flow of $\mathrm{Zn}$ and Cd was not enough to account for their uptake by $T$. caerulescens in a range of contaminated soils.

The low concentrations of $\mathrm{Zn}$ and $\mathrm{Cd}$ in all other parts of the roots are a typical feature of all hyperaccumulator plants as shown by several authors (e.g. Baker et al. 1994; Brown et al. 1995; Shen et al. 1997). Hyperaccumulators usually have a more efficient transport of specific metals from the roots to the shoots in comparison to non-hyperaccumulating plants.

In the leaves of $A$. halleri, trichomes appear to strongly accumulate both $\mathrm{Zn}$ and $\mathrm{Cd}$, both being sequestered in a small compartment at the trichome base. This occurred even when the concentrations of $\mathrm{Zn}$ and $\mathrm{Cd}$ in nutrient solution were relatively low. In a number of other plant species, sequestration of metals in trichomes has been reported, for example lead in Nicotiana tabacum (Martell 1974), Cd in Brassica juncea (Salt et al. 1995), manganese in Helianthus annuus (Blamey et al. 1986), and nickel in the Ni-hyperaccumulator Alyssum lesbiacum (Krämer et al. 1997). In particular, Blamey et al. (1986) found that manganese was accumulated in the basal compartment of trichomes in sunflower leaves in a pattern similar to that for $\mathrm{Zn} / \mathrm{Cd}$ observed in this study. They suggested that trichomes accumulated excess manganese from the surrounding tissues in this species. Part of the manganese can then possibly be secreted as an insoluble oxide. However, in our study, no apparent secretion of $\mathrm{Cd}$ or $\mathrm{Zn}$ was observed. The chemical forms of $\mathrm{Zn}$ and $\mathrm{Cd}$ accumulated in the trichome bases of $A$. halleri remain to be determined. Our results indicate that $\mathrm{P}$ and $\mathrm{S}$ were not 

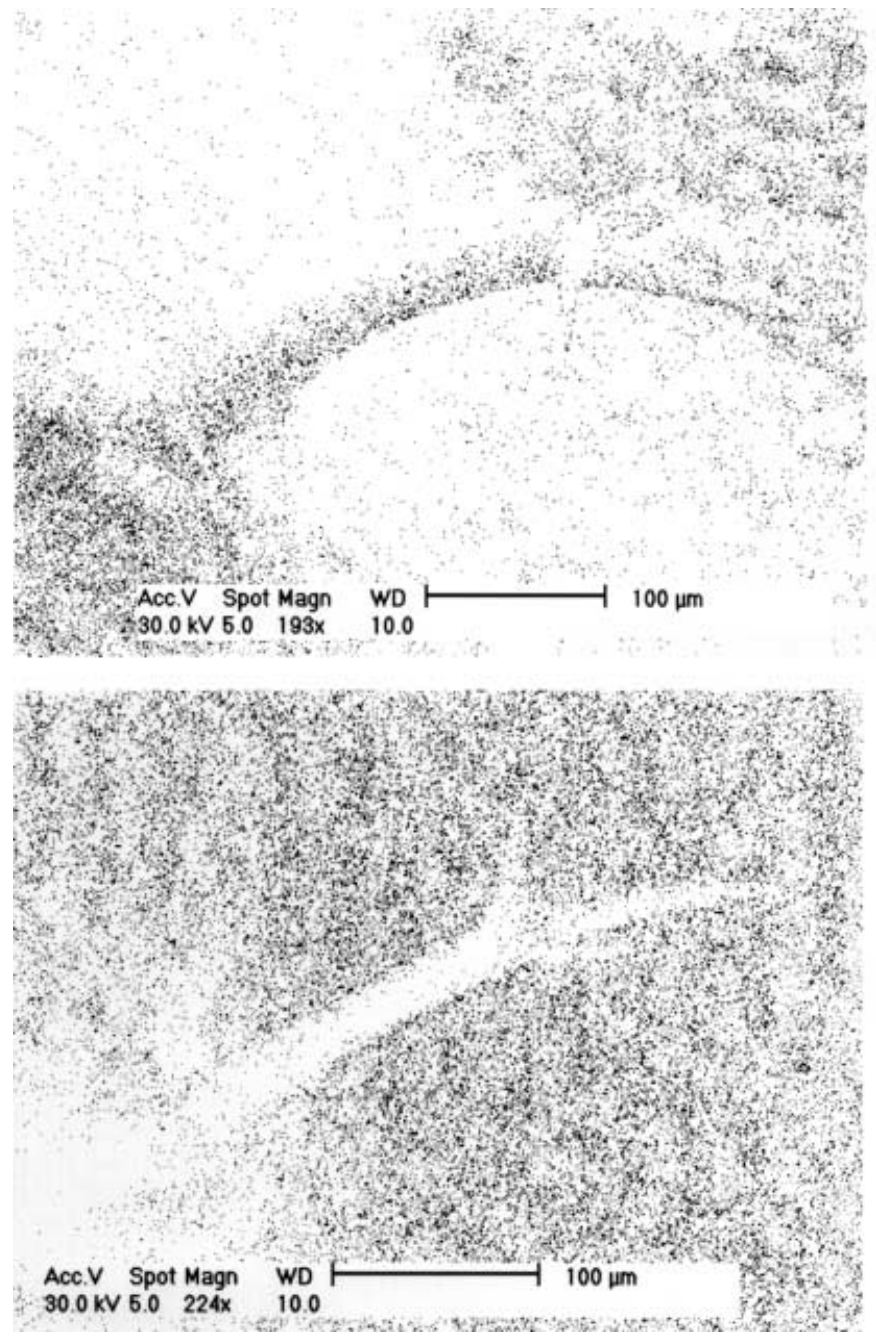

Fig. 5. Distribution of zinc in dead and living trichomes of $A$. halleri treated with $5 \mu \mathrm{M} \mathrm{Zn}$. Dot maps of EDXA counts. Upper, living trichome; lower, dead trichome; left, distribution of oxygen, showing
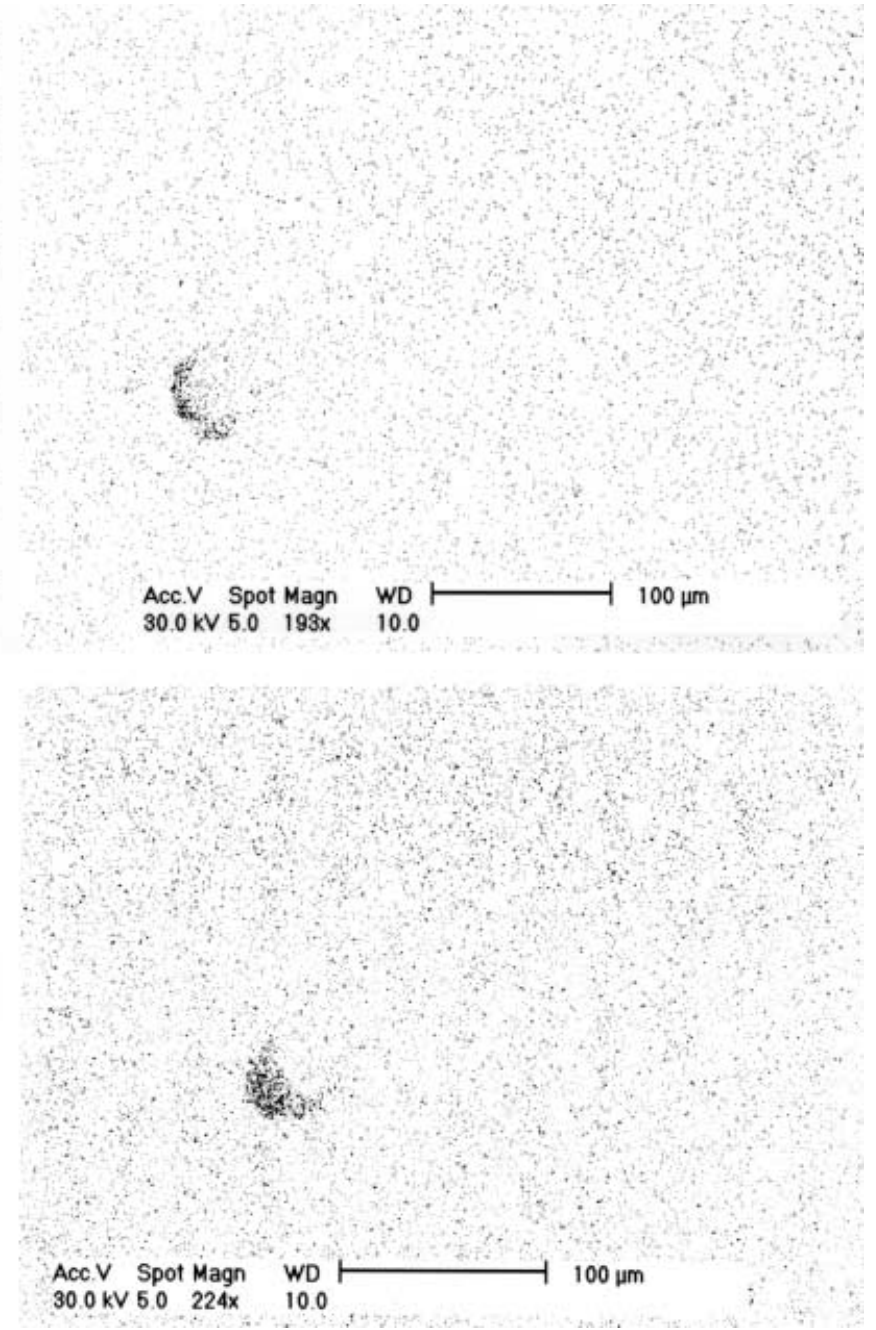

that the living trichome is hydrated while the dead one is dry; right, distribution of zinc. See Fig. 2 for explanation of SEM parameters

vacuoles, keeping the concentrations in the cytoplasm low.

The pattern of cellular distribution of $\mathrm{Zn}$ in $A$. halleri leaves differs greatly from that found in T. caerulescens (Küpper et al. 1999). In the latter, $\mathrm{Zn}$ is accumulated preferentially in the epidermal cells, whereas mesophyll cells have much lower concentrations. The difference between the two species is probably due to the fact that the epidermal cells of $A$. halleri, except trichomes, are very small (8-30 $\mu \mathrm{m}$ in length). In $T$. caerulescens, there is a large variability in epidermal cell size $(10-100 \mu \mathrm{m}$ in length) and Küpper et al. (1999) reported a strong correlation between the size of a cell and its average $\mathrm{Zn}$ concentration. This is important in this context because large cells usually have a higher degree of vacuolation than smaller ones in the same tissue. Small sizes of vacuoles in the epidermal cells of $A$. halleri would explain the low accumulation of $\mathrm{Zn}$ and $\mathrm{Cd}$ in these cells. The pattern of $\mathrm{K}$ distribution in the leaf cells of $A$. halleri was also opposite to that observed in T. caerulescens (Küpper et al. 1999). Both patterns of and $\mathrm{Zn}$ may be compartmented in a similar way. This seems to involve sequestration of both metals in the 

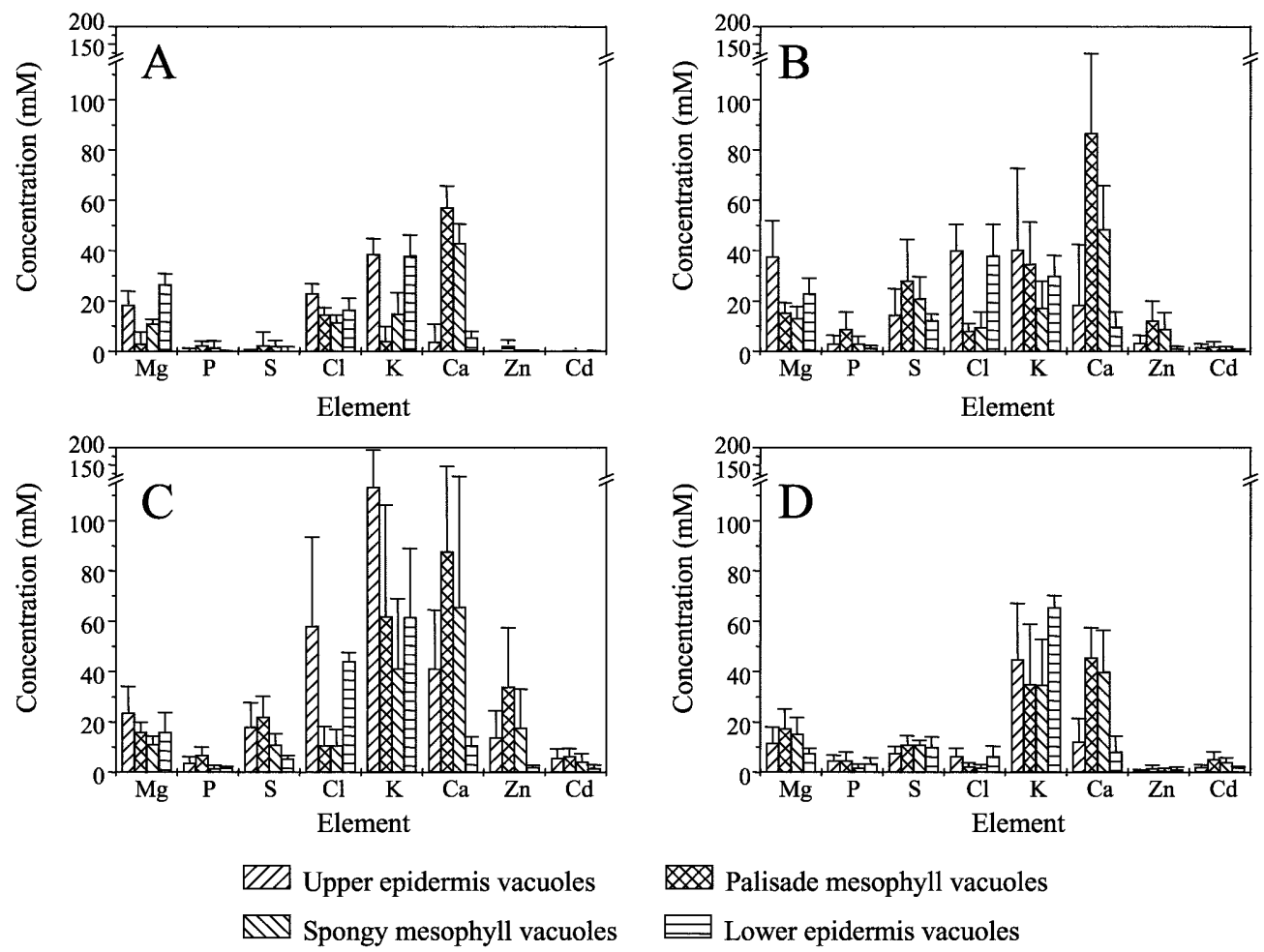

Fig. 6A-D. X-ray microanalysis data from different leaf tissues of A. halleri. A Control (5 $\mu \mathrm{M} \mathrm{Zn})$. B Grown with $500 \mu \mathrm{M}$ Zn. C Grown with $500 \mu \mathrm{M}$

Palisade mesophyll vacuoles $\mathrm{Zn}+100 \mu \mathrm{M}$ Cd. D Grown with $5 \mu \mathrm{M} \mathrm{Zn}+100 \mu \mathrm{M} \mathrm{Cd}$

$\mathrm{K}$ distribution could be explained by an osmotic adjustment by the plants to balance $\mathrm{Zn} / \mathrm{Cd}$ in different cell types.

\section{Conclusions}

The present work shows the potential for Cd hyperaccumulation in $A$. halleri. This may be of importance for soil remediation technologies based on metal extraction by plants such as phytoremediation (McGrath et al. 2000). Moreover, the results presented here represent the first quantitative study of cellular compartmentation of heavy metals in $A$. halleri. In the root, both $\mathrm{Cd}$ and $\mathrm{Zn}$ seem to form precipitates with $\mathrm{P}$ in the apoplast of the rhizodermis but their concentrations in the rest of the root are generally low. In the leaves the largest concentration of metals was recorded at the base of trichomes. However the mesophyll seems to play an important role in the hyperaccumulation capacity of this species, at least when very large amount of metals are accumulated in the leaves. This result is in contrast to the mechanism of compartmentation reported for the only other known $\mathrm{Cd}$ and $\mathrm{Zn}$ hyperaccumulator $T$. caerulescens. Further study should specifically address the role of vacuolation in the mesophyll cells in metal detoxification and the relationship, at single-cell level, between metal accumulation and cell damage.

We thank Chris Smith and Phil Jones for technical assistance in using the SEM and EDAX systems, and Sarah Dunham for help with setting up the plant experiments. We gratefully acknowledge financial support from DG XII of the European Commission for the PHYTOREM Project. IACR-Rothamsted receives grant-aided support from the Biotechnology and Biological Sciences Research Council of the United Kingdom.

\section{References}

Baker AJM (1981) Accumulators and excluders - strategies in the response of plants to heavy metals. J Plant Nutr 3: 643-654

Baker AJM, McGrath SP, Reeves RD, Smith JAC (2000) Metal hyperaccumulator plants: a review of the ecology and physiology of a biochemical resource for phytoremediation of metalpolluted soils. In: Terry N, Bañuelos G (eds) Phytoremediation of contaminated soil and water. Lewis, Boca Raton, Fla, pp 85107

Baker AJM, Reeves RD, Hajar ASM (1994) Heavy metal accumulation and tolerance in British populations of the metallophyte Thlaspi caerulescens J. \& C. Presl (Brassicaceae). New Phytol 127: 61-68

Blamey FPC, Joyce DC, Edwards DG, Asher CJ (1986) Role of trichomes in sunflower tolerance to manganese toxicity. Plant Soil 91: 171-180

Boekestein A, Thiel F, Stols ALH, Bouw E, Stadhouders AM (1984) Surface roughness and the use of a peak to background ration in the X-ray analysis of bio-organic bulk specimens. J Microsc 134: 327-333

Brooks RR (1998) Geobotany and hyperaccumulators. In: Brooks RR (ed) Plants that hyperaccumulate heavy metals. CAB International, Wallingford, UK, pp 55-94

Brooks RR, Lee J, Reeves RD, Jaffre T (1977) Detection of nickeliferous rocks by analysis of herbarium species of indicator plants. J Geochem Explor 7: 49-57

Brown SL, Chaney RL, Angle JS, Baker AJM (1995) Zinc and cadmium uptake by the hyperaccumulator Thlaspi caerulescens grown in nutrient solution. Soil Sci Soc Am J 59: $125-133$

Kneer R, Zenk MH (1992) Phytochelatins protect plant enzymes from heavy metal poisoning. Phytochemistry 31: 2663-2667

Knight K, Zhao FJ, McGrath SP, Shen ZG (1997) Zinc and cadmium uptake by the hyperaccumulator Thlaspi caerulescens in contaminated soils and its effects on the concentration and chemical speciation of metals in soil solution. Plant Soil 197: $71-78$

Krämer U, Grime GW, Smith JAC, Hawes CR, Baker AJM (1997) Micro-PIXE as a technique for studying nickel localization in 
leaves of the hyperaccumulator plant Alyssum lesbiacum. Nucl Instrum Methods Physics Res B 130: 346-350

Küpper H, Küpper F, Spiller M (1996) Environmental relevance of heavy metal substituted chlorophylls using the example of water plants. J Exp Bot 47: 259-266

Küpper H, Zhao FJ, McGrath SP (1999) Cellular compartmentation of zinc in leaves of the hyperaccumulator Thlaspi caerulescens. Plant Physiol 119: 305-311

Lasat MM, Baker AJM, Kochian LV (1996) Physiological characterization of root $\mathrm{Zn}$ absorption and translocation to shoots in $\mathrm{Zn}$ hyperaccumulator and nonaccumulator species of Thlaspi. Plant Physiol 112: 1715-1722

Lasat MM, Pence NS, Garvin DF, Ebbs SD, Kochian LV (2000) Molecular physiology of zinc transport in the $\mathrm{Zn}$ hyperaccumulator Thlaspi caerulescens. J Exp Bot 51: 71-79

Lombi E, Zhao FJ, Dunham SJ, McGrath SP (2000) Cadmium accumulation in populations of Thlaspi caerulescens and Thlaspi goesingense. New Phytol 145: 11-20

Macnair MR, Bert V, Huitson SB, Saumitou-Laprade P, Petit D (1999) Zinc tolerance and hyperaccumulation are genetically independent characters. Proc R Soc Lond 226: 2175-2179

Marschner H (1995) Mineral nutrition of higher plants. Academic Press, London

Martell EA (1974) Radioactivity of tobacco trichomes and insoluble cigarette smoke particles. Nature 249: 215-217

McGrath SP (1998) Phytoextraction for soil remediation. In: Brooks RR (ed) Plants that hyperaccumulate heavy metals. CAB International, Wallingford, UK, pp 261-287

McGrath SP, Dunham SJ, Correll RL (2000) Potential for phytoextraction of zinc and cadmium from soils using hyperaccumulator plants. In: Terry N, Bañuelos G (eds) Phytoremediation of contaminated soil and water. Lewis, Boca Raton, Fla., pp 109-128

Parker DR, Norvell WA, Chaney RL (1995) GEOCHEM-PC - A chemical speciation program for IBM and compatible personal computers. In: Loeppert RH, Schwab AP, Goldberg S (eds) Chemical equilibrium and reaction models. Soil Science Society of America, American Society of Agronomy, Madison, Wis., pp 253-269

Salt DE, Prince RC, Pickering IJ, Raskin I (1995) Mechanisms of cadmium mobility and accumulation in Indian mustard. Plant Physiol 109: 427-433

Salt DE, Smith RD, Raskin I (1998) Phytoremediation. Annu Rev Plant Physiol Plant Mol Biol 49: 643-668

Salt DE, Prince RC, Baker AJM, Raskin I, Pickering IJ (1999) Zinc ligands in the metal hyperaccumulator Thlaspi caerulescens as determined using x-ray absorption spectroscopy. Environ Sci Technol 33: 712-717

Salt DE, Kato N, Krämer U, Smith RD, Raskin I (2000) The role of root exudates in nickel hyperaccumulation and tolerance in accumulator and nonaccumulator species of Thlaspi. In: Terry N, Banuelos G (eds) Phytoremediation of contaminated soil and water. Lewis, Boca Raton, Fla., pp $189-200$

Shen ZG, Zhao FJ, McGrath SP (1997) Uptake and transport of zinc in the hyperaccumulator Thlaspi caerulescens and the nonhyperaccumulator Thlaspi ochroleucum. Plant Cell Environ 20: 898-906

Steffens JC (1990) The heavy metal-binding peptides of plants. Annu Rev Plant Physiol Plant Mol Biol 41: 553-575

Tomos AD, Hinde P, Richardson P, Pritchard J, Fricke W (1994) Microsampling and measurements of solutes in single cells. In: Harris N, Oparka KJ (eds) Plant cell biology - a practical approach. IRC Press, Oxford, pp 297-314

Van Steveninck RFM, Van Steveninck ME (1991) Microanalysis. In: Hall JL, Hawes C (eds) Electron microscopy of plant cells. Academic Press, London, pp 415-455

Zhao FJ, Lombi E, Breedon T, McGrath SP (2000) Zinc hyperaccumulation and cellular distribution in Arabidopsis halleri. Plant Cell Environ 23: 507-514

Zhu YL, Pilon-Smith EAH, Tarum AS, Weber SU, Jouanin L, Terry N (1999) Cadmium tolerance and accumulation in Indian mustard is enhanced by overexpressing $\gamma$-glutamylcysteine synthetase. Plant Physiol 121: 1169-1177 